\title{
Enhancement of Mechanical Properties of Polymethylmetha- crylate Denture Base Material by Zirconium Oxide Nanofiller
}

\author{
Mohammed K Fahmi ${ }^{1}$, Mohamed I Ebrahim ${ }^{2}$, Pooja Arora ${ }^{3}$
}

\begin{abstract}
Aim: The aim of this work was to study the effect of adding zirconium oxide $\left(\mathrm{ZrO}_{2}\right)$ nanofiller at different concentrations $(0.5 \mathrm{wt} \%$, 1 wt $\%$, and $3 \mathrm{wt} \%$ ) on the impact strength (IS) and fracture toughness (FT) of heat-polymerized polymethylmethacrylate (PMMA).

Materials and methods: Zirconium oxide nanofiller $\left(\mathrm{ZrO}_{2}\right)$ was added at different concentrations ( $0.5 \mathrm{wt} \%, 1 \mathrm{wt} \%$, and 3 wt $\left.\%\right)$ to PMMA. Total of eighty specimens was prepared for both tests, 40 for an individual test. For the individual test, four groups were formed (10 specimens each). There were three experimental groups with $\mathrm{ZrO}_{2}$ powders at different concentrations $(0.5 \%$, $1 \%$, and $3 \%)$ by weight and one control group without any addition. For measuring IS, Charpy's impact test was used, and the universal testing machine was used for FT. The values obtained for IS and FT were tabulated and statistically analyzed. Analysis of variance (ANOVA) and Tukey's test were utilized to analyze the level of significance in between the obtained means of the various groups, where the level of significance was set at a $p$ value of $\leq 0.05$.
\end{abstract}

Results: Reinforcement of PMMA with $\mathrm{ZrO}_{2}$ nanofiller significantly increased the IS and FT values between study groups $(p=0.000)$. Highest values obtained for IS and FT by adding $3 \mathrm{wt} \%$ nanofiller were $3.89 \mathrm{~kJ} / \mathrm{m}^{2}$ and $2.76 \mathrm{MPa} . \mathrm{m}^{1 / 2}$, respectively in comparison to control values of $1.53 \mathrm{~kJ} / \mathrm{m}^{2}$ and $1.23 \mathrm{MPa} \cdot \mathrm{m}^{1 / 2}$.

Conclusion: It was found that addition of $\mathrm{ZrO}_{2}$ at different concentrations improved the values for IS and FT of PMMA in comparison to the control group. The maximum values were obtained with $3 \mathrm{wt} \%$ of $\mathrm{ZrO}_{2}$ nanofiller.

Clinical significance: $\mathrm{PMMA}$ resin with improved properties obtained by addition of $\mathrm{ZrO}_{2}$ nanofillers can serve in prosthodontic applications. Keywords: Denture base, Fracture toughness, Impact strength, Nanofiller, Polymethylmethacrylate, Resin, Zirconium oxide.

\section{INTRODUCTION}

The main goal of using removable dentures is to replace missing teeth and surrounding structures in oro-dental applications. PMMA is suffering from low flexural strength, impact strength and fatigue resistance, ${ }^{1,2}$ still it is the material of choice for fabrication of complete denture bases. This is due to the several advantages such as biocompatibility, color matching ability, ease of use, low cost and ease of finishing and polishing. ${ }^{3}$

The major problem of acrylic resin is that it is low in fracture toughness. Denture bases are exposed to two kinds of stresses. Intraorally repeated force by mastication that causes fatigue failure. Extraorally, dropping the prosthesis leads to impact failure. ${ }^{4}$

Seventy percent of dentures fracture within 3 years after fabrication. This is commonly caused by heavy biting and masticatory forces that lead to deformation, or it can be accidental damage; any factor that changes the distribution of stresses can cause a fracture. Most of the upper dentures fracture due to combined fatigue and impact failure. For lower dentures, fractures are mostly (80\%) due to an impact. Twenty-nine percent of the fractures are in mid-line, and $33 \%$ fractures occur due to debonded/ detached teeth. ${ }^{2}$ Fractures are more common in upper dentures compared to the lower dentures. ${ }^{5}$

The PMMA is weak in terms of mechanical properties, therefore, researchers are always in search of newer modified material with improved properties. ${ }^{6}$

Change of the composition of acrylic base materials for improvement in strength has been achieved by addition of a cross-linking agent or rubber group, ${ }^{4}$ frame of metal, ${ }^{7}$ oxides of metal, ${ }^{8}$ or various kinds of fibers. ${ }^{9}$ Despite the various researches conducted to enhance fracture resistance of acrylic resin, only some approaches gave positive results. ${ }^{10,11}$ The strengthening of $\overline{{ }^{1-3} \text { Department of Restorative Dental Sciences, Taif University, Al }}$ Huwaya, Taif, Kingdom of Saudi Arabia

Corresponding Author: Pooja Arora, Department of Restorative Dental Sciences, Taif University, Al Huwaya, Taif, Kingdom of Saudi Arabia, Phone: +966599790360, e-mail: vipinendodontist@gmail.com, pooja@ tudent.edu.sa

How to cite this article: Fahmi MK, Ebrahim MI, Arora P. Enhancement of Mechanical Properties of Polymethylmethacrylate Denture Base Material by Zirconium Oxide Nanofiller. World J Dent 2019;10(2): 114-118.

Source of support: This study was funded by the Deanship of Scientific Research, Taif University, KSA (Research project number 1-438-5839).

\section{Conflict of interest: None}

denture-base materials with metal-composite systems has been one of the approaches of prime interest. ${ }^{11}$

In need to have a denture resin material with improved strength, a ceramic filler like, $\mathrm{ZrO}_{2}$ can be incorporated in acrylic powder of PMMA. ${ }^{12}$ It is a biocompatible material that possesses high-fracture resistance and is being added to acrylic resin and other dental polymers, composites and ceramic materials to improve the fracture toughness. 13,14

It is suggested to add zirconia to heat cure acrylic resin to increase mechanical properties of the material; impact strength, flexural strength, ${ }^{15}$ compressive strength, fatigue strength, as well as its fracture toughness and hardness. ${ }^{16,17}$ It may also play a role in antifungal effect. ${ }^{18}$

In the present study, the addition of $\mathrm{ZrO}_{2}$ nanoparticles in different concentrations to PMMA was explored, for enhancement of values of IS and FT of PMMA resin. The null hypothesis was that

(c) The Author(s). 20190pen Access This article is distributed under the terms of the Creative Commons Attribution 4.0 International License (https://creativecommons. org/licenses/by-nc/4.0/), which permits unrestricted use, distribution, and non-commercial reproduction in any medium, provided you give appropriate credit to the original author(s) and the source, provide a link to the Creative Commons license, and indicate if changes were made. The Creative Commons Public Domain Dedication waiver (http://creativecommons.org/publicdomain/zero/1.0/) applies to the data made available in this article, unless otherwise stated. 
the added $\mathrm{ZrO}_{2}$ nanofiller has no effect on the impact strength and fracture toughness of PMMA.

\section{Materials and methods}

The present study was conducted in the Faculty of Dentistry, Taif University, Al Huwaya, Taif, Kingdom of Saudi Arabia. Eighty specimens were prepared in total from heat-polymerized acrylic resin powder Regular Vertex (Vertex-dental B.V., Joh.v. oldenbarneveltlaan 62, 3705 HJ Zesit, The Netherlands; Lot no.: XW341P03) and liquid Regular Vertex (Vertex- dental B.V., Joh.v. oldenbarneveltlaan 62, 3705 HJ Zesit, The Netherlands; Lot no.: XW464L0). Forty specimens were prepared for each type of test-IS and FT.

Group A was for IS testing and group B for FT testing. Both groups $A$ and $B$ were further divided into four subgroups; GA1-GA4 and GB1-GB4, respectively. Groups GA1 and GB1 were the control groups (PMMA specimens without any additives). Groups GA2-GA4 and GB2-GB4 were the experimental groups (containing $\mathrm{ZrO}_{2}$ nanofiller). Table 1 shows the various study groups with coding and specifications.

The average particle dimension for zirconium oxide nanofiller used was $\leq 100 \mathrm{~nm}$ (Sigma-Aldrich, St. Louis, MO, USA, Trade MKBV9830V). $\mathrm{ZrO}_{2}$ nanofiller was incorporated in heat cure acrylic resin (PMMA) at different concentrations $(0.5 \%, 1 \%$, and $3 \%)$ by weight after modification of nanofiller by a silane coupling agent PlusOne ${ }^{\mathrm{TM}}$ Bind Silane (GE Healthcare- Life Sciences, Netherlands; Lot no.: L544448214620). The coupling agent (3-trimethoxysilylprpoyl methacrylate; TMSPM) aided to form reactive groups by coating the filler. ${ }^{19}$ The powder/liquid ratio of acrylic resin was set at $2.5: 1$ by weight according to manufacturer's instructions, powder and liquid were mixed, packed and pressed at appropriate stage in the mold of each test used and then processed in the water bath at $78^{\circ} \mathrm{C}$ for 90 minutes according to manufacturer's instructions.

Table 1: Specimen groups with coding and specifications

\begin{tabular}{lll}
\hline Groups & Specimens code & Description \\
\hline Group A & GA1 (Control group) & PMMA matrix without filler \\
& GA2 & PMMA with 0.5wt\% $\mathrm{ZrO}_{2}$ \\
& GA3 & PMMA with 1wt\% $\mathrm{ZrO}_{2}$ \\
& GA4 & PMMA with 3wt\% $\mathrm{ZrO}_{2}$ \\
\hline Group B & GB1 (Control group) & PMMA matrix without filler \\
& GB2 & PMMA with 0.5wt\% $\mathrm{ZrO}_{2}$ \\
& GB3 & PMMA with 1wt\% $\mathrm{ZrO}_{2}$ \\
& GB4 & PMMA with 3wt $\% \mathrm{ZrO}_{2}$
\end{tabular}

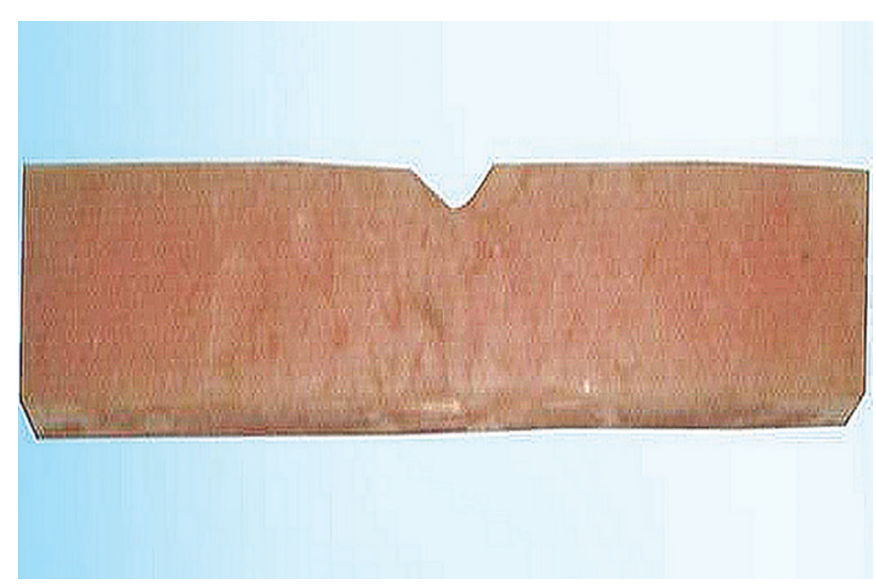

Fig 1: Specimen for impact strength testing

\section{Impact strength (IS) Testing}

The dimensions of the specimens within a flask were $80 \mathrm{~mm} \times 10$ $\mathrm{mm} \times 4 \mathrm{~mm}$, and width was $9.75 \mathrm{~mm}$ beneath the notch as per the requirement of the International Standards Organization (ISO) 179-A1:2005 (Fig. 1). The V-notch had a length of $0.25 \mathrm{~mm} \pm 0.05$ mm radius, angle notch sensitivity of $45^{\circ} \pm 1^{\circ}$ and the span support was $62 \pm 0.5 \mathrm{~mm}$.

The impact strength test (IS) was carried out by Charpy-type impact tester (Hounsfield plastic impact machine, Tensometer Ltd.) (Fig. 2). The prepared specimens were kept for 24 hours at $37^{\circ} \mathrm{C}$ in humidifier before IS testing. IS was calculated as loss of momentum in pendulum when the notched specimen was broken. To obtain real value, air force because of pendulum friction against air (-0.1 J) was subtracted. Prepared specimens were held in a horizontal position as a supported beam. Specimens were struck by the pendulum on the same plane of the notch but the opposite side in the middle. The specimens were tested, and the IS was calculated using equation $1:^{2}$

$$
\begin{gathered}
\text { IS }=\underline{E} \times 10^{3} \\
b_{n} d
\end{gathered}
$$

where, $\mathrm{E}$ is the energy absorbed by tested specimen on being impacted, $b_{n}$ is the width of the specimen $(\mathrm{mm})$ and $d$ is the thickness of specimen ( $\mathrm{mm}$ ).

\section{Fracture toughness (FT) Testing}

Specimens were fabricated in accordance with the ISO Specification No. 13586:2000. In the flask, specimens for FT measured $100 \mathrm{~mm}$ length $\times 20 \mathrm{~mm}$ width $\times 4 \mathrm{~mm}$ thickness with $4 \mathrm{~mm}$ of notch length (Fig. 3). Support span length was $64 \mathrm{~mm}$. A razor blade was tapped at the notch on the specimen to produce a crack.

The FT was determined using single edge span notch bending test (Fig. 4). Lloyd universal testing machine (model LRX plus II, Fareham, England) (Fig. 5) was used with a load cell of $5 \mathrm{kN}$ and a crosshead speed of $0.5 \mathrm{~mm} /$ minute. The prepared specimens were kept for 24 hours at $37^{\circ} \mathrm{C}$ in humidifier before testing. Specimens were loaded until fracture. The FT was determined in MPa. $\mathrm{m}^{1 / 2}$ using the equation $2:^{18}$

$$
\mathrm{FT}=\mathrm{pc} / \mathrm{bw}^{1 / 2} \times \mathrm{F}(\mathrm{a} / \mathrm{w})
$$

Where pc was maximum load (KN) before the crack advancement, $b$ was the thickness of specimen $(\mathrm{cm}), \mathrm{w}$ was the width of the specimen $(\mathrm{cm})$, a was the length of crack $(\mathrm{cm})$. F was calculated using the equation (3): ${ }^{18}$

$$
\begin{aligned}
& (2+\mathrm{a} / \mathrm{w})\left(0.886+\mathrm{a} / \mathrm{w}-13.32 \mathrm{a}^{2} / \mathrm{w}^{2}+\mathrm{a}^{3} / \mathrm{w}^{3}-5.6 \mathrm{a}^{4} / \mathrm{w}^{4}\right) \\
& \mathrm{F}=--\mathrm{a} / \mathrm{w})^{3 / 2}
\end{aligned}
$$

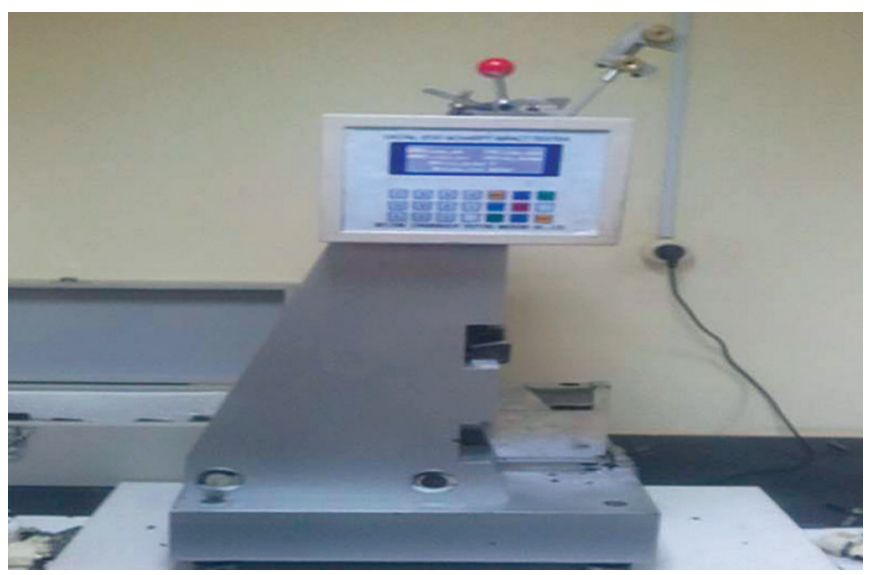

Fig 2: Charpy-type impact tester 


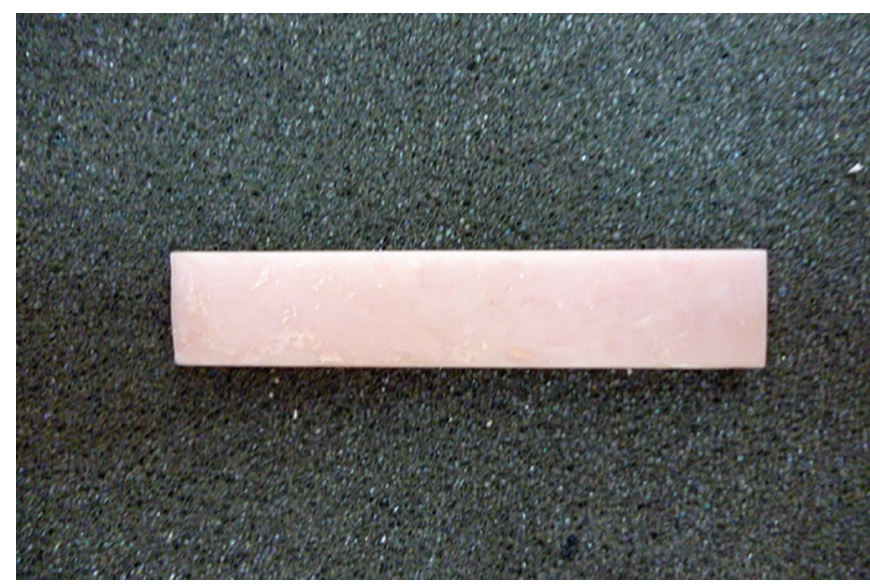

Fig 3: Specimen for fracture toughness testing

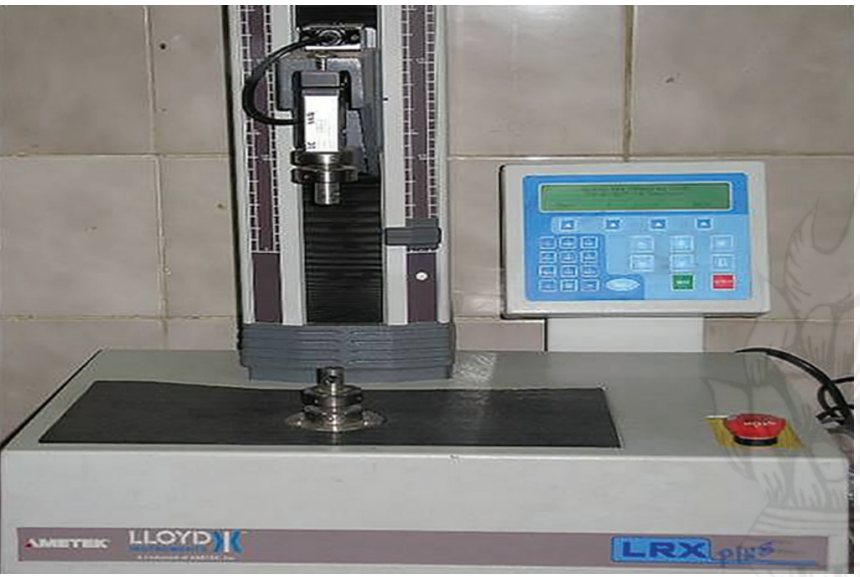

Fig 5: Universal testing machine

\section{Results}

\section{Statistical Analysis}

Values obtained for both the tests were utilized to calculate the respective means with standard deviation. ANOVA test was carried out to analyze if the difference in means between control and experimental groups was significant. Tukey's test was then applied for pairwise comparison between mean values after the results of the ANOVA test were found significant. Level of significance was set at $p \leq 0.05$. IBM statistical package for social sciences (SPSS, Inc., an IBM Company) statistics version 20 for windows was utilized for statistical analysis.

The mean, standard deviation values (SD) of IS and fracture toughness (FT) of the tested groups are summarized in Tables 2 and 3 , respectively. Statistically significant differences $(p \leq 0.05)$ for IS and FT were found between the control specimens without any nanofiller addition and the test specimens reinforced with $\mathrm{ZrO}_{2}$ nanofillers at different concentrations ( $0.5 \mathrm{wt} \%, 1 \mathrm{wt} \%$, and $3 \mathrm{wt} \%)$. There was a significant increase in mean IS and FT after adding $\mathrm{ZrO}_{2}$ nanofillers at different concentrations especially with $3 \mathrm{wt} \%$ of $\mathrm{ZrO}_{2}$.

For IS, the mean values obtained for groups GA1-GA4 were $1.53,1.95,2.93$ and 3.89 respectively. The increase in IS from group GA1 to GA4 was statistically significant ( $p \leq 0.05)$. A comparison of the IS mean values between the control group and experimental groups showed least value of IS for the control group (GA1) which was 1.53 and the highest value of 3.89 was recorded for the group containing $3 \mathrm{wt} \% \mathrm{ZrO}_{2}$ nanofiller (GA4).

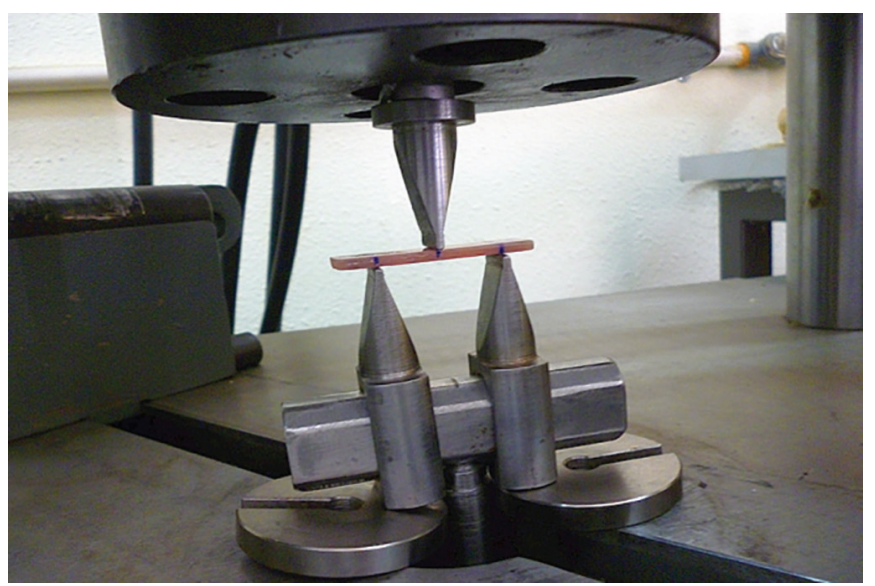

Fig 4: Fracture toughness testing on the universal testing machine

Table 2: Statistical analysis for impact strength $\left(\mathrm{kJ} / \mathrm{m}^{2}\right)$ of control and experimental groups.

\begin{tabular}{llll}
\hline Group & $\begin{array}{l}\text { Number of } \\
\text { specimens }\end{array}$ & Mean $\pm \mathrm{SD}$ & $p$ value \\
\hline $\mathrm{GA} 1$ (Control group) & 10 & $1.53^{\mathrm{d}} \pm 0.76$ & $0.000^{*}$ \\
$\mathrm{GA} 2\left(0.5 \mathrm{wt} \% \mathrm{ZrO}_{2}\right)$ & 10 & $1.95^{\mathrm{c}} \pm 0.63$ & \\
$\mathrm{GA3}\left(1 \mathrm{wt} \% \mathrm{ZrO}_{2}\right)$ & 10 & $2.93^{\mathrm{b}} \pm 0.56$ & \\
$\mathrm{GA} 4\left(3 \mathrm{wt} \% \mathrm{ZrO}_{2}\right)$ & 10 & $3.89^{\mathrm{a}} \pm 1.05$ & \\
\hline
\end{tabular}

*Significant at $p \leq 0.05$; Ranks a, b, c and d for Turkey's test refer to the significant difference among means of various groups

Similar results were obtained for $\mathrm{FT}$. The mean values obtained for groups GB1-GB4 were 1.23, 1.86, 2.27 and 2.76, respectively. The increase in IS from group GB1 to GB4 was statistically significant $(p \leq 0.05)$. Comparison of the FT mean values between the control group and experimental groups showed least value of FT for the control group (GB1) which was 1.23 and the highest value of 2.76 was recorded for the group containing 3 wt $\% \mathrm{ZrO}_{2}$ nanofiller (GB4).

\section{Discussion}

Since many years, PMMA resin is being utilized in making of partial and complete dentures for edentulous patients. However, acrylic dentures suffer from a high fracture rate due to inferior mechanical properties of the resin. So, several researchers tried to enhance these properties of acrylic resin material through different ways: by chemical modification of PMMA, or reinforcing PMMA with other materials. More recently, increasing the strength of PMMA resin in terms of flexural and impact strength by incorporation of nanoparticles in the resin is being tried. 2,20 $^{2}$

In the present study, $\mathrm{ZrO}_{2}$ nanofillers were chosen for incorporation in the resin matrix due to several advantages: excellent biocompatibility, improved mechanical properties, white color that does not remarkably affects denture esthetics, better dispersion and the ability to eliminate plaque aggregation with improved compatibility with an organic polymer. ${ }^{21,22}$ However, according to some authors, the percentage range of $\mathrm{ZrO}_{2}$ nanofillers must not exceed $7 \%$ as it can lead to massive color changes in acrylic resin. ${ }^{23}$

The incidence of fractures in PMMA dentures is decreasing as research continues to enhance the mechanical properties of PMMA resin. ${ }^{24}$ In the present research, the effect of adding zirconium oxide nanofiller at different concentrations on IS and FT of heat cured PMMA was studied. 
The impact strength is the ability of a material to resist a sudden high-level force or "shock". High impact strength is required to avoid the fracture when the patients accidentally drop their dentures. ${ }^{25}$ It was determined using the Charpy-type impact test.

Regarding impact strength (IS), the control group A1 had the lowest IS due to its brittle nature. There was a significant increase in IS as the concentration of $\mathrm{ZrO}_{2}$ fillers increased as shown in Table 2. The values of IS for various experimental groups with $\mathrm{ZrO}_{2}$ nanoparticles at different concentrations were higher than those in the control group due to the interaction between the silanized zirconium oxide nanofillers with the resin matrix. Uniform dispersion of nanofillers in polymer and cross-linking between the nanofillers and resin matrix prevents the propagation of cracks by shielding the nanofillers. ${ }^{26}$ The smaller size of $\mathrm{ZrO}_{2}$ nanofillers used in this study led to an increase in surface area that was utilized for dissipation of energy. Also, critical stress required for interfacial debonding increases which increases IS. ${ }^{27}$ Similar observations were made by researchers like Alhareb ${ }^{28}$ who incorporated silanized ceramic fillers ( $2.5 \mathrm{wt} \%$ alumina and $2.5 \mathrm{wt} \%$ yttria stabilized zirconia) into conventional heat-cured denture base resin along with nitrile butadiene rubber particles and $\mathrm{Al}-\mathrm{Hiloh}^{29}$ who added 3 wt $\%$ concentration of silanized nano $\mathrm{ZrO}_{2}$ fillers into high-impact heat-cured denture base resin.

However, researchers like Ayad $^{30}$ did not find any increase in the impact strength of the resin tested. This could be due to the difference in the particle size of the filler used. Also, the workers used higher concentrations (5 and $15 \mathrm{wt} \%$ ) of the filler.

Fracture toughness (FT) is regarded as an important property while evaluating dental polymers. ${ }^{31}$ It characterizes the mechanical behavior of polymer under load to determine maximum force tolerated by polymer before the fracture. ${ }^{32}$ Varieties of tests can be used to evaluate FT. The single-edge-notched specimen test was used because of validity, reliability and ease of sample preparation. ${ }^{33}$

PMMA with no nanofiller had low fracture toughness compared to other formulations of PMMA with $\mathrm{ZrO}_{2}$ nanofiller. The highest values of FT were obtained with $3 \mathrm{wt} \%$ of filler content. While comparing the mean values, there was a significant difference in FT values for PMMA with $3 \% \mathrm{ZrO}_{2}$ when compared to those of other study groups as shown in Table 3.

The improvement in fracture toughness can be attributed to the uniform distribution of fine nanofillers that fill the interstitial spaces in the polymer matrix, thus restricting the segmental motions of the macromolecules and causing an improvement in fracture resistance. ${ }^{34}$ The strong interfacial bonding between silanized $\mathrm{ZrO}_{2}$ filler particles and molecules of resin that helps cover filler particles prevents the propagation of crack and in turn, increases $\mathrm{FT}^{7}$ Transformation toughening is also responsible for this improvement in FT. When a crack begins to propagate under stress, $\mathrm{ZrO}_{2}$ transforms from metastable tetragonal to stable monoclinic phase that leads to

Table 3: Statistical analysis for fracture toughness $\left(\mathrm{MPa}^{\mathrm{m}} \mathrm{m}^{1 / 2}\right)$ of control and experimental groups

\begin{tabular}{llll}
\hline Group & $\begin{array}{l}\text { Number of } \\
\text { specimens }\end{array}$ & Mean \pm SD & p value \\
\hline $\mathrm{GB} 1$ (Control group) & 10 & $1.23^{\mathrm{d}} \pm 0.86$ & $0.000^{*}$ \\
$\mathrm{~GB} 2\left(0.5 \mathrm{wt} \% \mathrm{ZrO}_{2}\right)$ & 10 & $1.86^{\mathrm{c}} \pm 0.67$ & \\
$\mathrm{~GB} 3\left(1 \mathrm{wt} \% \mathrm{ZrO}_{2}\right)$ & 10 & $2.27^{\mathrm{b}} \pm 1.07$ & \\
$\mathrm{~GB} 4\left(3 \mathrm{wt} \% \mathrm{ZrO}_{2}\right)$ & 10 & $2.76^{\mathrm{a}} \pm 0.64$ & \\
\hline
\end{tabular}

*Significant at $p \leq 0.05$; ranks $\mathrm{a}, \mathrm{b}, \mathrm{c}$ and $\mathrm{d}$ for Turkey's test refer to the significant difference among means of various groups depletion of energy for the propagation of the crack. Also, there is an expansion of $\mathrm{ZrO}_{2}$ particles that places crack in state of compressive stress and crack propagation is arrested. ${ }^{35,36}$ Both mechanisms improve the FT of PMMA denture base under masticatory loads.

Ahmed $M A^{18}$ found the highest value of fracture toughness with $3 \mathrm{wt} \%$ concentration of $\mathrm{ZrO}_{2}$ nanofiller. But the values did not improve significantly at the higher concentrations of filler (5-7 wt\%). It could be attributed to over saturation of resin matrix with the filler. ${ }^{37}$ Alhareb ${ }^{28}$ also observed that the value of fracture toughness was maximum when the concentration of yttria-stabilized zirconia used was $2.5 \mathrm{wt} \%$.

The results of the present study are in accordance with other researchers who observed that reinforcement of acrylic resins, ceramics and restorative resins with $\mathrm{ZrO}_{2}$ nanofillers can lead to an improvement in various properties like impact strength and fracture toughness. ${ }^{37,38}$

However, the present study was limited to using a few concentrations ( $0.5 \mathrm{wt} \%, 1 \mathrm{wt} \%$ and $3 \mathrm{wt} \%$ ) $\mathrm{ZrO}_{2}$ nanofiller. Also, the effect of zirconium oxide addition was studied only on two mechanical properties (impact strength and fracture toughness) of PMMA. Also, further clinical research needs to be done to validate the results of this study.

\section{Conclusion}

Within the limitations of the present study, the conclusions drawn were:

- Addition of Zirconium oxide nanofillers at $0.5 \mathrm{wt} \%, 1 \mathrm{wt} \%$ and $3 \mathrm{wt} \%$ to heat polymerized PMMA increased impact strength and fracture toughness of PMMA.

- The best results were observed using the concentration of $3 \% \mathrm{wt}$ of zirconium oxide nanofiller.

- When high impact strength and fracture toughness are needed, PMMA denture base reinforced with zirconium oxide nanofillers is a good choice in removable prosthodontics.

Further studies are required to evaluate the effect of zirconium oxide addition on other properties of PMMA with different concentrations.

\section{Clinical SIgnificance}

PMMA resin with improved properties obtained by addition of $\mathrm{ZrO}_{2}$ nanofillers can serve in prosthodontic applications.

\section{References}

1. Nejatian T, Johnson A, Van Noort R. Reinforcement of denture base resin. Adv Sci Tech. 2006; 49:124-129.

2. Kim SH, Watts DC. The effect of reinforcement with woven E-glass fibers on the impact strength of complete dentures fabricated with high-impact acrylic resin. J Prosthet Dent 2004;91:274-280.

3. John J, Gangadhar S, Shah I. Flexural Strength of heat-polymerized polymethyl methacrylate denture resin reinforced with glass, aramid, or nylon fibers. J Prosth Dent 2001;86:424-427.

4. Rakhshan V. Marginal integrity of provisional resin restoration materials: a review of the literature. Saudi J Dent Res 2015;6:33-40.

5. El-Sheikh AM, Al-Zahrani SB. Causes of denture fracture: A survey. Sau Dent J 2006;18:149-154.

6. Vallittu $P$, Alakuijala $P$, Lassila $V$, et al. In vitro fatigue fracture of an acrylic resin-based partial denture: An exploratory study. J Prosth Dent 1994;72:289-295.

7. Knott N. The durability of acrylic complete denture bases in practice. Quint Inter 1989;20:341-343.

8. Balch J, Smith P, Marin M, et al. Reinforcement of a mandibular complete denture with internal metal framework. J Prosth Dent 2013;109:202-205. 
9. Venkat R, Gopichander N, Vasantakumar M. Comprehensive analysis of repair/reinforcement materials for polymethyl methacrylate denture bases: Mechanical and dimensional stability characteristics. $J$ Ind Prosth Soci 2013;13:439-449.

10. Xu J, Li Y, Yu T, Cong L. Reinforcement of denture base resin with short vegetable fiber. Dent Mater J 2013;29:1273-1279.

11. Franklin P, Wood D, Bubb N. Reinforcement of poly (methyl methacrylate) denture base with glass flake. Dent Mater J 2005; 21:365-370.

12. Arora P, Singh SP, Arora V. Effect of Alumina Addition on Properties of Poly-methyl methacrylate. A Comprehensive Review. Int J Biotech Trends Technol. 2015;5(1):1-7.

13. Asar N, Albayrak H, Korkmaz T, et al. Influence of various metal oxides on mechanical and physical properties of heatcured polymethyl methacrylate denture. J Adv Prosth. 2013; 5: 241-247.

14. Avila-Herrera CA, Gomez-Guzman O, Almaral-Sanchez JL, et al. Mechanical and thermal properties of SiO2-PMMA monoliths. J NonCryst Solids. 2006; 352:3561-3566.

15. Skukla S, Seal S. Phase stabilization in nano crystalline zirconia. Rev Adv Mat Sci. 2003; 5:117-120.

16. Gad M, ArRejaie AS, Abdel-Halim MS, et al. The reinforcement effect of nano-zirconia on the transverse strength of repaired acrylic denture base. Int J Dent 2016;2016:1-6.

17. Salih SI, Oleiwi JK, Hamad QA. Investigation of fatigue and compression strength for the PMMA reinforced by different system for denture applications. Int J Biomed Mat Res 2015;3:5-13.

18. Ahmed MA, Ebrahim MI. Effect of Zirconium Oxide Nano-Fillers Addition on the Flexural Strength, Fracture Toughness, and Hardness of Heat-Polymerized Acrylic Resin. World Journal of Nano Science and Engineering 2014;4:50-57.

19. Cierech M, Kolenda A, Grudniak AM, et al. Significance of PMMA (PMMA) modification by zinc oxide nanoparticles for fungal biofilm formation. Int J Pharm 2016; 510:323-335.

20. Uzun G, Hersek $N$, Tincer $T$. The effect of five woven fiber reinforcements on the impact and transverse strength of a denture base resin. J Prosthet Dent 1999;81:616-620.

21. Jagger D, Harrison A, Jandt K. The reinforcement of dentures. J Ora Reha. 1999;26:185-194.

22. Suna L, Gibson R, Gordaninejad F, et al. Energy absorption capability of nanocomposites: A review. Compos Sci Technol 2009;69:2392-2309.

23. Ihab N, Hasanayn K, Ali N. Assessment of zirconium oxide nano-fillers incorporation and silanation on impact, tensile strength and color alteration of heat polymerized acrylic resin. J Bag Coll Dent 2012; 24:36-42.
24. Shi J, Bao Y, Huang Z, et al. Preparation of poly (methyl methacrylate)/ nanometer calcium carbonate composite by in-situ emulsion polymerization. J Zhej Uni Sci A. 2004; 5:709-713.

25. Ellakwa AE, Morsy MA, El-Sheikh AM. Effect of Aluminum oxide addition on the flexural strength and thermal diffusivity of heatpolymerized acrylic resin. J Prosthodont 2008;17(6):439-444.

26. Sun L, Ronald FG, Suhr J, et al. Energy absorption capability of nano composites: A review. Compos Sci Technol. 2009; 69: 2392-2409.

27. Chen JK, Huang ZP, Zhu J. Size effect of particles on the damage dissipation in nanocomposites. Compos Sci Technol 2007; 67(14):2990-2996.

28. Alhareb AO, Akil HM, Ahmad ZA. Impact strength, fracture toughness and hardness improvement of PMMA denture base through addition of nitrile rubber/ceramic fillers. Saudi J Dental Res 2017;8: 26-34.

29. Al-Hiloh SA, Ismail IJ. A Study the Effect of Addition of Silanized Zirconium Oxide Nanoparticles on Some Properties of High-Impact Heat-Cured Acrylic Resin. J Bagh College Dentistry 2016;28(2):19-25.

30. Ayad N, Badawi M, Fatah AA. Effect of reinforcement of highimpact acrylic resin with zirconia on some physical and mechanical properties. Rev Clín Pesq Odontol 2008;4:145-151.

31. Zappini G, Kammann A, Wachter W, Comparison of fracture tests of denture base materials. J Pros Dent 2003;90:578-585.

32. Soderholm K. Review of the fracture toughness approach. Dent Mat J 2010;26:63-77.

33. Schulze K, Zaman A, Söderholm K. Effect of filler fraction on strength, viscosity and porosity of experimental compomer materials. J Dent 2003;31:373-382.

34. Katsikis N, Franz Z, Anne H, et al. Thermal stability of PMMA/ Silica nano- and micro composites as investigated by dynamic-mechanical experiments. Polym Degra and Stability 2007; 22:1966-1976.

35. Anusavice KJ. Phillips' science of dental materials. 11th ed. Philadelphia, PA: Saunders; 2003. p. 703-704.

36. Saini J, Arora P, Arora G. Zirconia- a ceramic steel: a biomaterial. Scholar's Press; 2015. Available at:https://www.scholars-press.com/ catalog/details//store/gb/book/978-3-639-76262-4/zirconia-ceramicsteel:a-biomaterial

37. Vojdani M, Bagheri R, Khaledi AAR. Effects of Aluminum Oxide Addition on the Flexural Strength, Surface Hardness, and Roughness of Heat-Polymerized Acrylic Resin. Dental Journal of Sciences, 2012;7:238-244.

38. Furman $B$, Rawls HR, Wellinghoff $S$, et al. Metal-Oxide Nanoparticles for the Reinforcement of Dental Restorative Resins. Crit Rev Biomed Eng. 2000;28:439-443. 